\title{
The impact of infrastructure on driver behavior on pedestrian crossings - case studies in two Mazovian cities
}

\author{
Maciej Sulmicki
}

\begin{abstract}
In 2019 field studies were conducted in order to check how various aspects of pedestrian and cycle crossing infrastructure influence driver behavior. The overall goal was to verify the adequacy of the road safety-related provisions of the main strategic and planning documents of the Mazovia Region. The crossings analyzed in Warsaw and Radom were chosen so as to take into account all the types of traffic calming mentioned in the Spatial Development Plan of Mazovia as serving to improve safety on pedestrian crossings. Other aspects taken into account included road width, type of intersection and presence/type of traffic lights.

The field studies focused on the behavior of drivers towards pedestrians and cyclists, including behavior which determines how quickly a driver can react to a non-motorized person appearing. The crossings were observed from a distance, so that the presence of the observer wouldn't influence the participants' behavior. Each crossing was observed and recorded for at least thirty minutes in order to identify how often a driver: stops before a crossing, drives across in front of or behind a non-motorized person, stops on the crossing or drives fast across it. In selected places, another recorded aspect was whether the driver looks around before driving across the crossing. However, such detailed observation was not possible in the majority of places due to high traffic and/or inadequate visibility of the interiors of cars. The field studies in Radom were conducted by Sebastian Pawłowski and Łukasz Zaborowski of the Radom branch of the Mazovian Office for Regional Planning.

The study results indicate that dangerous driver behavior is influenced by: the width of the road on the crossing, bicycle crossings and right-of-way provisions, physical traffic calming measures and traffic lights. Measures which were found to be ineffective include hatched road markings signaling a part of the road which is not to be driven across and red lights with a green arrow allowing for a conditional right-turn after stopping, which were in fact treated as green right-turn lights.

The study confirmed the accuracy of the measures indicated in the strategic and spatial planning documents of the Mazovia Region, as well as the need for them to be implemented more often. An analysis of the field study results allowed for the identification of the impact of individual road crossing parameters on drivers' behavior, thus providing new material in reference to earlier local studies and a 2018 Polish national study.

A Polish version of this article will also be published in a later issue of this periodical.
\end{abstract}

Key words: road safety, pedestrian crossings, vulnerable road users, traffic calming

\section{Introduction}

Poland is one of the most dangerous European Union countries in terms of probability of death in a road accident. The number of road fatalities per million inhabitants in Poland is 
around 50\% higher than the European Union average [Skoczyński, Wacowska-Ślęzak 2019, p. 4, Fig. 3]. Around one third of those fatalities are pedestrians. In absolute numbers, this means that the number of pedestrian fatalities in Poland is the highest in the EU-28. It is nearly twice as high as in Germany, even though the Polish population is over two times smaller; it is two and a half times higher than in Spain, the population of which is larger by a quarter. Such a situation in Poland is the result of several factors, including faulty legal regulations, the lack of effective execution of regulations and errors in the planning and building of infrastructure.

A key element of infrastructure in terms of pedestrian safety is the intersection of pedestrian and car routes, i.e. pedestrian crossings. There should be places where it is possible to safely cross the road, as underlined by regulations giving priority to pedestrians on the crossing $^{1}$, although the pedestrians are required to exercise particular caution, as are drivers nearing a crossing.

According to Art. 26 of the Polish highway code, "A driver nearing a pedestrian crossing is obliged to exercise particular caution and give way to a pedestrian on the crossing." "Giving way" is earlier defined as "refraining from movement, if such movement could cause (...) a pedestrian to stop, slow down or quicken their pace". It is also forbidden to overtake another vehicle on a crossing or stop thereupon (past the conditional stop line).

The exercising of caution by drivers is particularly problematic in Poland. This has been confirmed by a study commissioned by the National Road Safety Council (Krajowa Rada Bezpieczeństwa Ruchu Drogowego) in the last four months of 2018. While the studies did not indicate significant problems with improper behavior on the part of pedestrians, $85-90 \%$ of drivers did not respect the speed limit when approaching a pedestrian crossing. A positive correlation was identified between the speed and road width [Ministerstwo Infrastruktury, Sekretariat KRBRD 2019, p. 77].

Other studies conducted in previous decades (mostly in the United Kingdom and Scandinavia) indicate a correlation between drivers' behavior on crossings and the crossings' parameters and elements. A positive impact on safety was identified in the case of raised pedestrian crossings, ones equipped with refuge islands and ones where the road was narrowed. A negative impact of traffic lights was identified if the lights were programmed so that a car could have a green light at the same time as a pedestrian on a crossing the car could drive across (i.e. after a right turn) [cf. Vaa 2006, p. 4]. Studies in Poland focused on the way the behavior of drivers was determined by the road width (number of lanes) and the presence of traffic lights, not taking into account the presence of traffic calming measures and road curve radius [cf. Budzyński, Jamroz, Mackun 2017; Ministerstwo Infrastruktury, Sekretariat KRBRD 2019, p. 9].

\footnotetext{
${ }^{1}$ As this article was being written, the law clarifying the priority of pedestrians entering the crossing in Poland was still under preparation. During the field studies, the regulation of July 31, 2002 on road signs specified that a driver nearing a crossing identified by a relevant sign is obliged to slow down, so as to avoid endangering pedestrians or cyclists on such a crossing or entering it.
} 
The results of the National Road Safety Council studies were made public in July 2019. At the same time, employees of the Mazovian Office for Regional Planning were conducting field studies in Warsaw and Radom ${ }^{2}$ so as to identify the influence of infrastructure on drivers' behavior on pedestrian and bicycle crossings. The elements taken into account included road width, traffic calming and traffic lights. The results were presented during the 10th Active Mobility Congress (X Kongres Mobilności Aktywnej) in September 2019 and later served as the basis for this article. The overarching goal of the studies was to verify the accuracy of the pedestrian safety-related provisions of the regional development strategy and spatial development plan of Mazovia.

\section{Road safety in Mazovian documents}

The Development Strategy of the Mazowieckie Voivoidship 2030. Mazovia as an Innovative Region, adopted in 2013, emphasizes the importance of safe and effective infrastructure for the non-motorized in the transport system. The diagnosis in terms of "Space and transportation" points to the fact that "the impact of a road on the accessibility of an area is determined by such elements as pedestrian and bicycle infrastructure and adaptation to the needs of the elderly and people with reduced mobility". The SWOT analysis points to the challenge of "increasing the role of public transport and pedestrian and bicycle traffic in the transport system", while among the opportunities are "road construction projects as an opportunity for increasing pedestrian and bicycle traffic through implementing solutions corresponding to the needs of the non-motorized". One of those needs is doubtlessly being able to safely cross the road.

One of the policy directions in the strategy is "Developing environmentally sustainable and accessible forms of transport" which includes two actions relevant from the point of view of pedestrian/bicycle crossing safety:

- increasing the modal share of walking and cycling,

- improving road safety, i.e. through limited-speed zones with traffic calming in built-up areas.

These provisions show that the Regional Government of Mazovia intends to ensure conditions for safe and effective non-motorized mobility. The problem of safety is presented in greater detail in The Spatial Development Plan for the Mazowieckie Voivodeship adopted in 2018. The document points to the need to improve road safety through:

- building sidewalks, bicycle tracks, pedestrian and cycle crossings,

- implementing solutions serving to improve road safety, i.e. limited-speed zones and traffic calming (speed humps, raised crossings, refuge islands, raised intersections, small roundabouts).

The part of the plan devoted to the Warsaw functional area also points to the need to increase the modal share of walking and cycling. This is in line with the Development Strategy

\footnotetext{
${ }^{2}$ Both cities accounted for 45\% of road accidents involving pedestrians in the Mazovia region in 2017-2019.
} 
of the Warsaw Metropolitan Area 2030 which underlines that the traffic management hierarchy in a modern metropolis needs to prioritize pedestrian and bicycle traffic, as well as public transport, rather than individual motor vehicles.

It is the second point from the regional spatial development plan that the field studies were most directly concerned with: improving road safety through traffic calming: raised crossings and intersections, refuge islands and small roundabouts. The effectiveness of each of these solutions was verified in the context of the other policy elements concerning increasing the modal share of pedestrian and bicycle traffic. The verification consisted of observation of 20 places with pedestrian crossings, in some cases accompanied by bicycle crossings.

\section{Characteristics of the observation points}

The 20 crossings/intersections observed were situated in Warsaw (15) and Radom (5) (cf. Fig. 1). In terms of types of infrastructure, they consisted of:

- 6 crossings not situated on intersections,

- 6 crossings across three-way $(\mathrm{T})$ intersections without traffic lights,

- 5 crossings across intersections with traffic lights,

- 3 crossings across roundabout arms.

The choice of locations allowed for the analysis of driver behavior towards pedestrians and cyclists on the following types of crossings:

- raised crossings,

- crossings not situated on intersections with refuge islands,

- crossings not situated on intersections without refuge islands,

- raised intersections,

- small and medium roundabouts,

- crossings and intersections with traffic lights, both with the conditional permission for vehicles to turn right after stopping (green arrows) and without it.

The locations were thus chosen so as to include all the types of traffic calming mentioned in the Spatial Development Plan for the Mazowieckie Voivodeship in reference to improving road safety on pedestrian crossings. Table 1 presents a full list of the crossings analyzed.

Table 1. Analyzed pedestrian and bicykle crossings

\begin{tabular}{|l|c|c|r|}
\hline City & Street / intersection & Lanes $^{3}$ & Type of crossing/intersection \\
\hline Warsaw & Grzybowska 5 & $2 \times 2$ & $\begin{array}{r}\text { Pedestrian crossing not situated on intersection } \\
\text { with refuge island }\end{array}$ \\
\hline Warsaw & Paryska 14 i 16 & $2 \times 1$ & $\begin{array}{r}\text { Pedestrian (and bicycle) crossing not situated on } \\
\text { intersection with refuge island }\end{array}$ \\
\hline
\end{tabular}

${ }^{3}$ Number of carriageways and number of lanes in each carriageway. 


\begin{tabular}{|c|c|c|c|}
\hline City & Street / intersection & Lanes $^{3}$ & Type of crossing/intersection \\
\hline Radom & Sienkiewicza 16 & $1 \times 2$ & $\begin{array}{r}\text { Raised pedestrian crossing not situated on } \\
\text { intersection }\end{array}$ \\
\hline Warsaw & Polska 33 & $1 \times 2$ & $\begin{array}{r}\text { Street-level pedestrian (and bicycle crossing) } \\
\text { not situated on intersection }\end{array}$ \\
\hline Radom & Wałowa / Rwańska & $1 \times 2$ & $\begin{array}{r}\text { Street-level pedestrian not situated on } \\
\text { intersection }\end{array}$ \\
\hline Warsaw & $\begin{array}{c}\text { Teodorowicza / } \\
\text { Klimczaka }\end{array}$ & $1 \times 2$ & Three-way $(\mathrm{T})$ raised intersection \\
\hline Radom & $\begin{array}{l}\text { Niedziałkowskiego } \\
\text { / Skłodowskiej }\end{array}$ & $1 \times 2$ & Three-way $(\mathrm{T})$ raised intersection \\
\hline Warsaw & $\begin{array}{l}\text { Matejki / } \\
\text { al. Ujazdowskie }\end{array}$ & $1 \times 2$ & Three-way $(\mathrm{T})$ street-level intersection \\
\hline Warsaw & $\begin{array}{l}\text { Nowolipki / } \\
\text { Andersa }\end{array}$ & $1 \times 3$ & $\begin{array}{r}\text { Three-way }(\mathrm{T}) \text { street-level intersection with } \\
\text { hatched road markings signaling a part of the } \\
\text { road which is not to be driven across }\end{array}$ \\
\hline Warsaw & $\begin{array}{c}\text { Wędrowców / } \\
\text { Puławska }\end{array}$ & $1 \times 2$ & $\begin{array}{r}\text { Three-way }(\mathrm{T}) \text { intersection with raised } \\
\text { pedestrian and bicycle crossing }\end{array}$ \\
\hline Warsaw & $\begin{array}{l}\text { Srebrna / } \\
\text { Towarowa }\end{array}$ & $1 \times 2$ & $\begin{array}{r}\text { Three-way }(\mathrm{T}) \text { intersection with raised } \\
\text { pedestrian and bicycle crossing }\end{array}$ \\
\hline Warsaw & $\begin{array}{c}\text { Klimczaka / } \\
\text { Sarmacka }\end{array}$ & $2 \times 1$ & Small one-lane roundabout (24-meter radius) \\
\hline Warsaw & $\begin{array}{l}\text { Żegańska / } \\
\text { Dworcowa }\end{array}$ & $2 \times 2$ & $\begin{array}{r}\text { Medium two-lane roundabout (42-meter radius, } \\
\text { 25-meter island) }\end{array}$ \\
\hline Radom & $\begin{array}{c}\text { Rondo } \\
\text { Dmowskiego }\end{array}$ & $2 \times 2$ & $\begin{array}{r}\text { Medium two-lane roundabout (43-meter radius, } \\
28 \text {-meter island) }\end{array}$ \\
\hline Warsaw & $\begin{array}{l}\text { Nowy Zjazd } \\
\text { / Wybrzeże } \\
\text { Kościuszkowskie }\end{array}$ & $3+1$ & $\begin{array}{r}\text { Three-way }(\mathrm{T}) \text { intersection with traffic lights, } \\
\text { incl. green arrows, and refuge island }\end{array}$ \\
\hline Warsaw & $\begin{array}{l}\text { Sierakowskiego / } \\
\text { al. Solidarności }\end{array}$ & $1 \times 4$ & $\begin{array}{r}\text { Three-way }(\mathrm{T}) \text { intersection with traffic lights, } \\
\text { incl. green arrows, without refuge island }\end{array}$ \\
\hline Warsaw & $\begin{array}{l}\text { al. Rzeczypospolitej } \\
\text { / Klimczaka }\end{array}$ & $2 \times 2$ & $\begin{array}{r}\text { Four-way intersection with traffic lights, incl. } \\
\text { green arrows, and refuge island }\end{array}$ \\
\hline Warsaw & Nugat / Rosoła & $2 \times 2$ & $\begin{array}{r}\text { Four-way intersection with traffic lights, incl. } \\
\text { green arrows, and refuge island }\end{array}$ \\
\hline Radom & $\begin{array}{l}25 \text { Czerwca / } \\
\text { Żeromskiego }\end{array}$ & $2+3$ & $\begin{array}{r}\text { Four-way intersection with traffic lights, incl. } \\
\text { green arrows, and refuge island }\end{array}$ \\
\hline
\end{tabular}

${ }^{4}$ The crossing is on a three-way intersection, but the third arm is a one-way street, with traffic allowed only away from the crossing, not towards it. 


\begin{tabular}{|l|l|c|r|}
\hline City & Street / intersection & Lanes $^{3}$ & Type of crossing/intersection \\
\hline Radom & Grzecznarowskiego & $2 \times 2$ & $\begin{array}{r}\text { Pedestrian crossing not situated on intersection } \\
\text { with refuge island }\end{array}$ \\
\hline
\end{tabular}

Source: own work
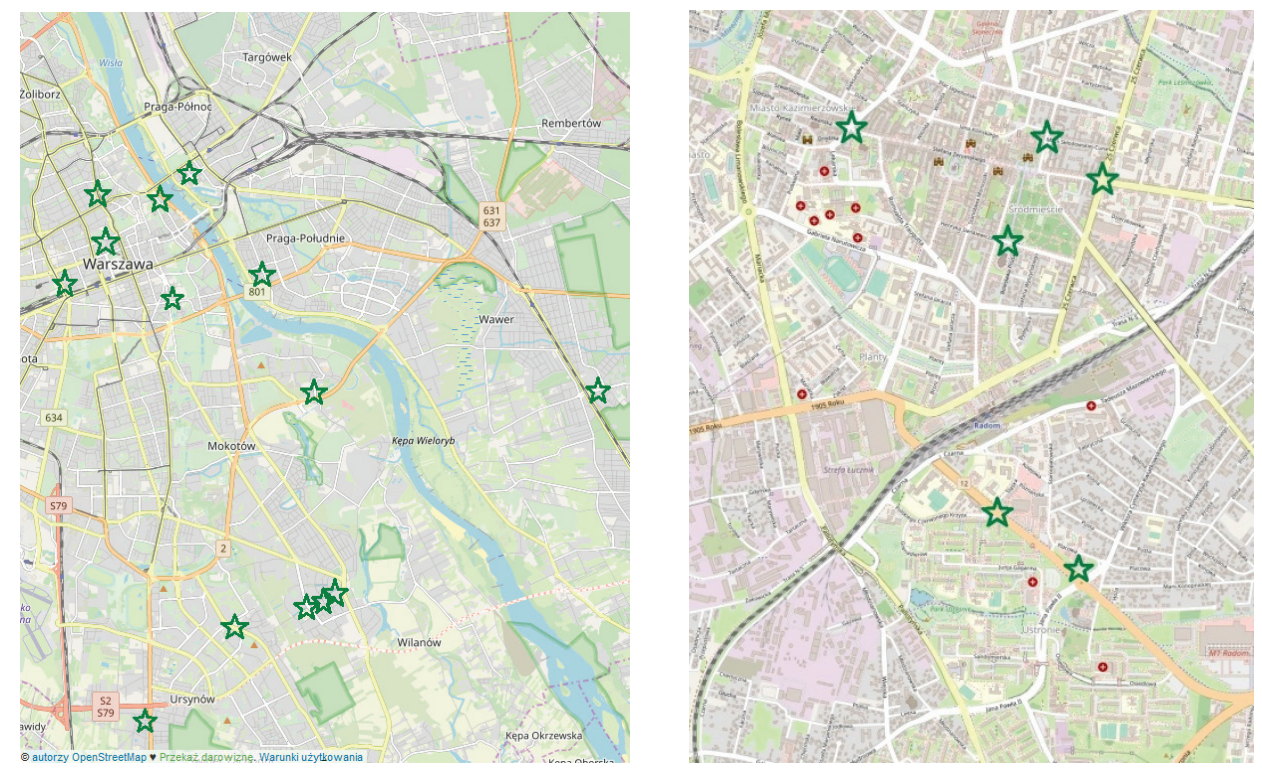

Fig. 1. Location of the analyzed crossings in Warsaw (left) and Radom (right)

Background source: Open Street Map

The field studies consisted of observing driver behavior towards pedestrians and cyclists, including behavior which determined how quickly a driver could react to a non-motorized person appearing. The crossings were observed from a distance, so that the presence of the observer would not influence the participants' behavior. Each crossing was observed and recorded for at least thirty minutes in order to identify how often: a driver stops before a crossing, drives across in front of or behind a non-motorized person, stops on the crossing or drives fast across it. ${ }^{5}$ In selected places, another recorded aspect was whether the driver looked around before driving across the crossing. However, such detailed observation was not possible in the majority of places due to high traffic and/or inadequate visibility of the interiors of cars.

\footnotetext{
${ }^{5}$ Speed was assessed by the observer, as the subjective speed from the point of view of the non-motorized, without exact measurements.
} 


\section{Study results}

\section{Pedestrian crossings not situated on intersections}

The analyzed pedestrian crossings not situated on intersections were chosen, taking into account road width, the presence of a refuge island and whether the crossing was raised or not. Five crossings were therefore chosen, three of them in Warsaw and two in Radom:

- 1 across a four-lane road with a refuge (crossing across two two-lane carriageways ${ }^{6}: 2 \times 2$ ),

- 1 across a two-lane road with a refuge $(2 \times 1)$,

- 1 raised crossing across a single-carriageway two-lane road (1×2),

- 2 without traffic calming across a single-carriageway two-lane road (1x2).

The field studies indicated a significant difference in driver behavior, dependent primarily on the road width and whether the crossing was raised, so as to function as a speed bump. A correlation between visibility and driver alertness was also observed.

The crossing at Grzybowska 5 leads across two 3-meter lanes leading east and one 5.5-meter lane leading west. Therefore, overtaking is possible on the crossing in both directions, although in the western direction it is much rarer for two cars to approach the crossing simultaneously. The carriageways are separated by a 1.6-meter refuge island, shorter than the legal minimum of 2 meters. Both before and after the island, the carriageways are separated by a fence. The visibility is good, limited only by trees before the crossing on one side of the road. Apart from the standard "pedestrian crossing" sign, there is also a "children crossing" (T-27) one. Pedestrian traffic on the crossing is high, as it is situated in a densely built-up part of the city center.

The default driving style among drivers was to approach the crossing fast. The drivers were not observed to look around before approaching the crossing, unless there was already a pedestrian on the crossing or in its direct vicinity. If there was a pedestrian on the crossing or approaching it, only $55 \%$ of the drivers stopped before the crossing and $7 \%$ did so on the crossing. 30\% drove across it fast despite the presence of a non-motorized person, including $17 \%$ who drove fast in front of a pedestrian on the crossing or entering it (cf. Figs. 2 and 3). Additionally, $38 \%$ of the drivers drove across the crossing behind a pedestrian, not waiting until he left it. A positive aspect observed was that the pedestrians did not have to wait to cross the road - the non-motorized traffic flow was rather smooth. Also observed was the traffic-calming effect of cars parking on the road behind the crossing, functioning as a chicane, i.e. forcing drivers approaching the crossing in the right lane to switch lanes.

\footnotetext{
${ }^{6}$ Formally, the road has three lanes on the crossing (at Grzybowska 5): two on the southern carriageway and one on the northern one. However, the northern carriageway is two lanes wide 20 meters earlier and its width (5.5 meters) remains sufficient for cars to overtake each other on the crossing. It was therefore qualified as a $2 \times 2$ road.
} 

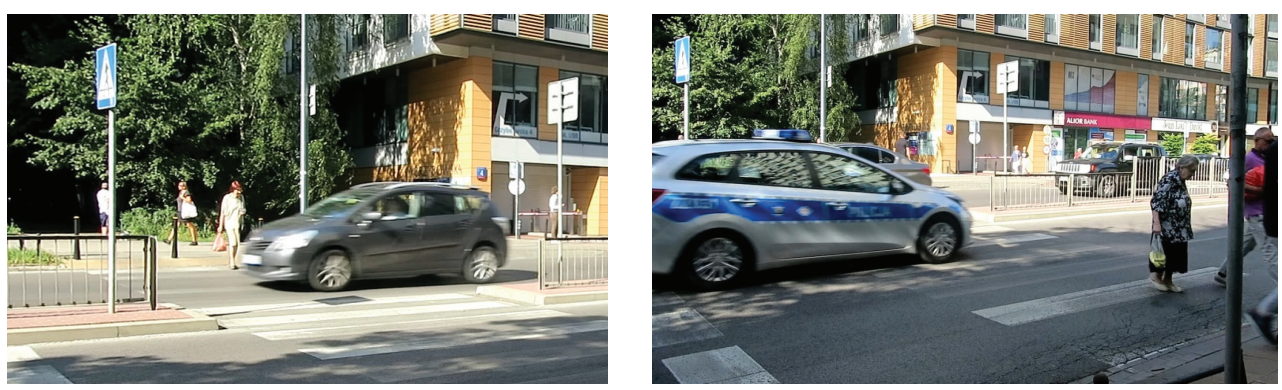

Figs. 2 and 3. Driver behavior towards pedestrians on the crossing across Grzybowska in Warsaw driving across the crossing in front and behind pedestrians

Phot. M. Sulmicki

The pedestrian and bicycle crossings at Paryska 14 and 16 lead across two 4.5-meter lanes, one in each direction, separated by a 3-meter refuge (cf. Fig. 4). Above the road between the crossings, which are situated 40 meters apart, there is an overpass, the pillars of which limit visibility on the second crossing in each direction. Before the refuge islands, there are parking lanes - in effect, the car trajectory bends slightly before the crossing in order to avoid the refuge. However, apart from the refuge island itself, the parts of the road on which driving is forbidden were marked only by hatched road markings. The pedestrian and bicycle traffic was moderate.

The width of the lanes enabled driving across the crossing even if pedestrians were there, but the 1-1.5-meter smaller width in comparison to Grzybowska significantly limited drivers' tendency to do so. A greater vigilance was also visible on the part of drivers approaching the view-limiting pillars after driving across the first crossing. On the northern crossing, drivers' behavior was observed in terms of whether they looked around before driving across: $57 \%$ did, regardless of whether there was a non-motorized person in the field of view. When there was a pedestrian or cyclist on the crossing or nearing it, $71 \%$ of drivers stopped before the crossing and $4 \%$ on it. $14 \%$ drove fast across the crossing despite the presence of a non-motorized person, including $4 \%$ who drove fast in front of a person who was on the crossing or entering it. A further 13\% drove behind a non-motorized person on the crossing, not waiting for him to leave it.

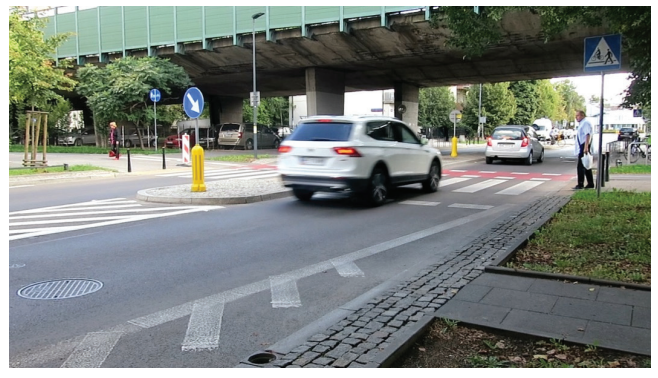

Fig. 4. Pedestrian and bicycle crossing near Paryska 14 in Warsaw

Phot. M. Sulmicki 
The pedestrian and bicycle crossing at Polska 33 is similar to the one on Paryska, as it runs parallel to an overpass. Visibility is limited on one side by an embankment and pillars, and - on the other side - by a fence and trees. There is another similar crossing on the other side of the overpass, but as visibility was limited, only the northern one was observed. The street is 6 meters wide and there are warning signs before the crossing.

The non-motorized traffic consisted mostly of bicycles and its intensity was limited. Nevertheless, a high degree of vigilance on the part of the drivers was visible. $73 \%$ clearly looked around and $47 \%$ stopped before the crossing, regardless of whether there was a non-motorized person visible. A further 5\% stopped on the crossing, usually in cases when they entered the crossing while looking around and saw a cyclist approaching. Fewer than 15\% drove fast across the crossing, but in none of these cases was there a non-motorized person present. There were also no cases of driving in front of/behind a pedestrian or cyclist in the process of crossing the road.

The crossing at Wałowa in Radom had some similar characteristics, as visibility there is limited when approaching from the south by a building and there is earlier a one-lane roundabout which calms the traffic coming from the north. The road is c. 7 meters wide on the crossing (it widens towards the roundabout). The crossing is located in the city center and the pedestrian traffic is high. The car traffic was also higher than in the case of the previous crossing discussed.

No cases of driving fast across the crossing were observed and the number of drivers stopping on the crossing was near zero. However, a significantly higher share of drivers $(20 \%)$ drove in front of a pedestrian entering the crossing or waiting to cross, as well as in front of ones already on the crossing (2\%). A further $23 \%$ drove behind such a pedestrian.

The crossing at Sienkiewicza in Radom is raised to sidewalk level and links a park with a church (cf. Fig. 5). The visibility on the side of the church is limited by perpendicular parking spaces directly before the crossing. The road width is 9 meters. The pedestrian traffic was moderate.

In this case, no stopping on the crossing was observed and the number of drivers driving fast across was also negligible $(<1 \%)$. The large road width resulted in frequent driving across the crossing while pedestrians were present, both in front of and behind them ( $24 \%$ of drivers in total).

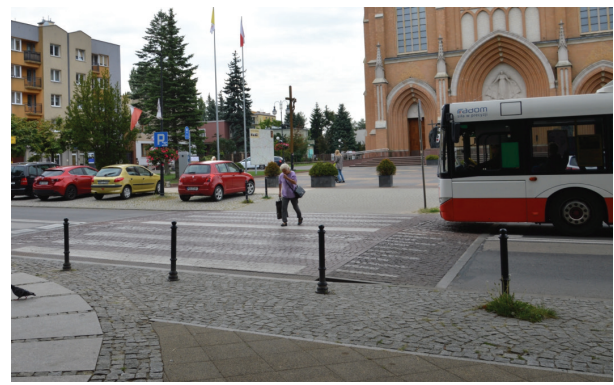

Fig. 5. Crossing at Sienkiewicza 33 in Radom

Phot. S. Pawłowsk 
The field studies confirmed the dependence of driver behavior on road width and traffic calming measures. A correlation is visible between the road width and the frequency of driving fast across a crossing despite the presence of a non-motorized person, with the exception of the elevated crossing which functioned as a speed bump (Fig. 6). A similar correlation is visible with the frequency of driving across a crossing on which there is a pedestrian, although in this case whether the crossing is elevated is irrelevant (Fig. 7).

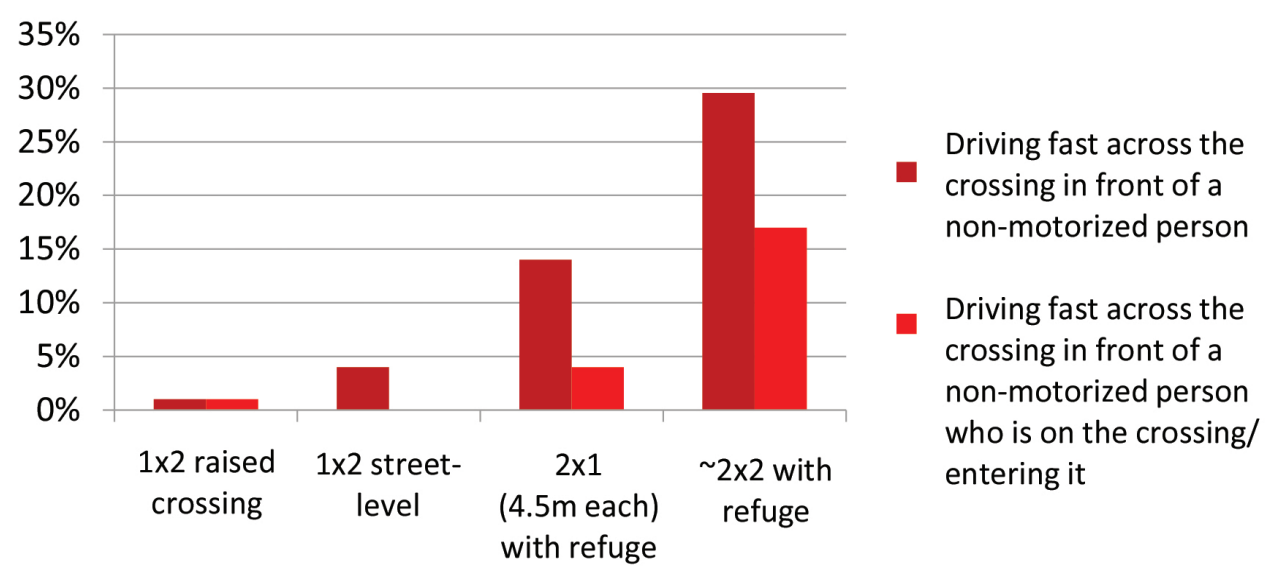

Fig. 6. Share of drivers driving fast across crossings on roads of different widths (number of carriageways $x$ number of lanes on each one) while a non-motorized person was present

Source: own work

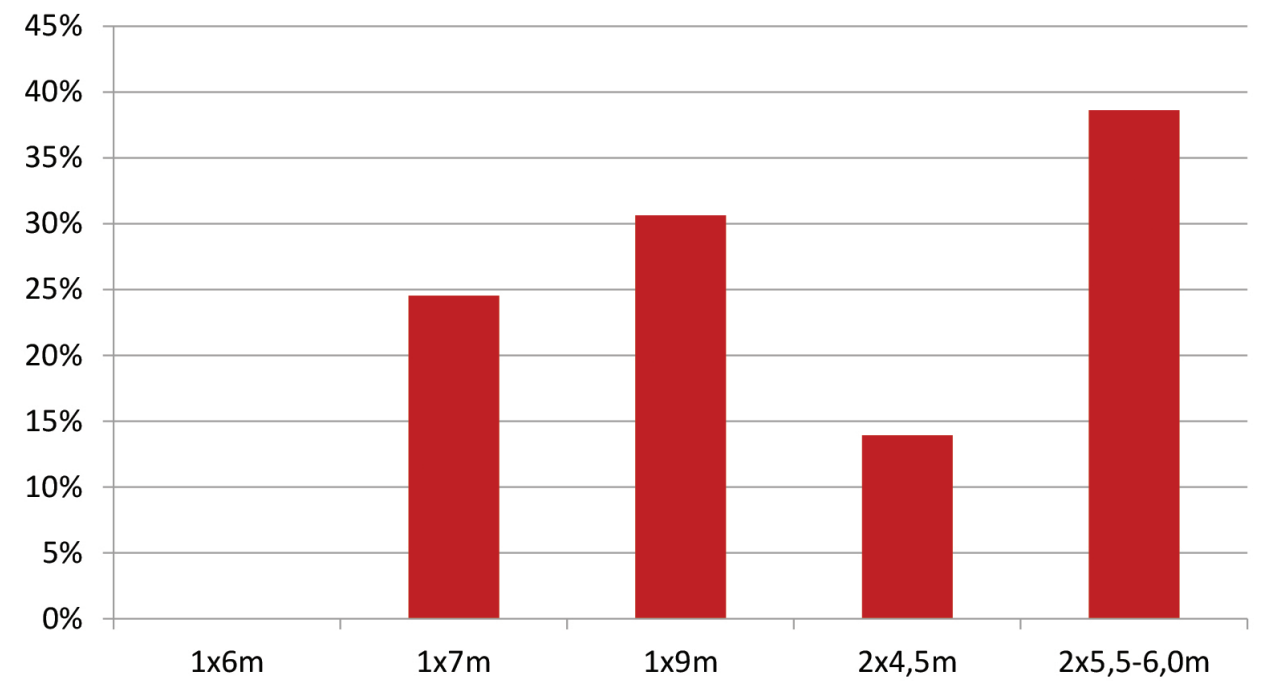

Fig. 7. Share of drivers driving across crossings on roads of different widths while a non-motorized person was present 
As a point of reference, one crossing not situated at an intersection with traffic lights was observed (at Grzecznarowskiego 17 in Radom), so that their efficacy in limiting dangerous behavior on the part of drivers could be analyzed. During 27 cycles, 47 cars drove past yellow and red lights, including 15 on red (during $55 \%$ of cycles) and 32 on yellow (during $89 \%$ of cycles). The lights changing and the wide road ( $3+2$ lanes) encouraged potentially dangerous behavior, in particular speeding up before the crossing.

\section{Pedestrian crossings on T-type intersections}

The crossings observed on T-type intersections without traffic lights were chosen so that different road widths and raised crossings/intersections would be taken into account. Thus, 5 crossings across two-way streets in Warsaw and 1 in Radom were chosen:

- 1 street-level crossing across two lanes (pedestrian and bicycle crossing across Matejki along Al. Ujazdowskie in Warsaw),

- 1 street-level crossing across three lanes with a painted "refuge" (across Nowolipki along Andersa in Warsaw),

- 2 raised ones across two lanes (pedestrian and bicycle crossings across Wędrowców along Puławska and across Srebrna along Towarowa in Warsaw),

- 2 crossings across two lanes on raised intersections (across Niedziałkowskiego on the intersection with Skłodowskiej-Curie in Radom and across two sides of the Klimczaka and Teodorowicza intersection in Warsaw).

Driver behavior was influenced by physical methods of traffic calming and road width. Only $3 \%$ of drivers drove fast across raised crossings or intersections which functioned as physical means of traffic calming. 4 times more (12\%) did so on the street-level crossing across two lanes $(6.2 \mathrm{~m})$ and five times more $(19 \%)$ on the street-level crossing across three lanes (13-16m) (cf. Fig. 8).

A significant influence of the road curve radius was observed. When turning right, $80 \%$ of drivers entered the turn into Nowolipki fast, while only $14 \%$ did so when turning into Matejki (with a significantly smaller curve radius). Other aspects resulting in different driver behavior could have been differences in lane width $(4.1 \mathrm{~m}$ vs $3.1 \mathrm{~m}$ at the beginning of the crossing), the distance to the crossing from the intersection (cf. Fig. 9) and the presence of a bicycle crossing across Matejki. The latter appeared to encourage drivers to more cautious behavior due to the legal obligation to give way to a cyclist moving in a straight line. The non-motorized traffic intensity was similar in both cases, although the share of bicycle traffic along Al. Ujazdowskie was significantly higher. 


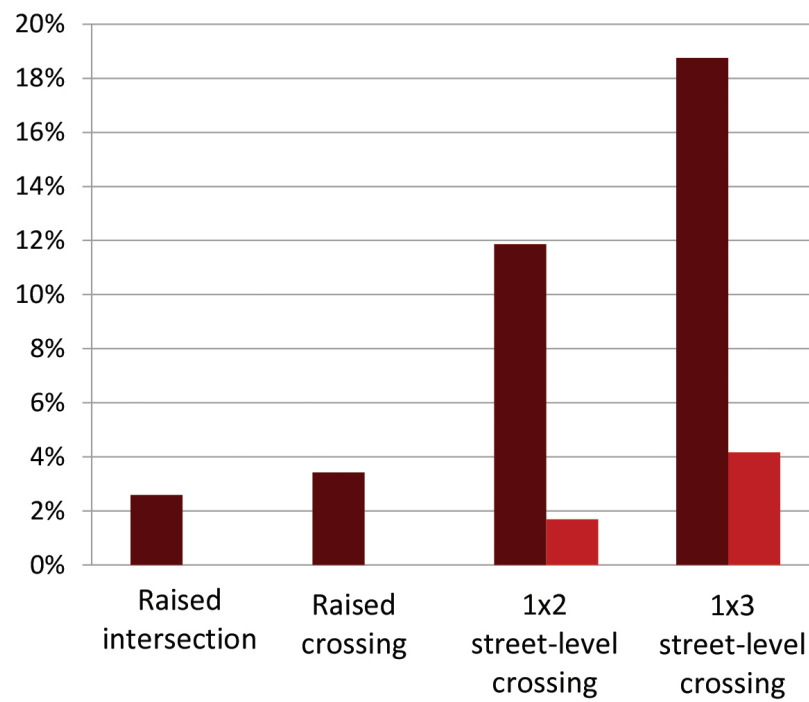

Driving fast across the crossing

Driving fast across the

crossing when a pedestrian is on it/entering it

Fig. 8. Share of drivers driving fast across crossings on roads of different widths (number of carriageways $x$ number of lanes on each one) on T-type intersections

Source: own work
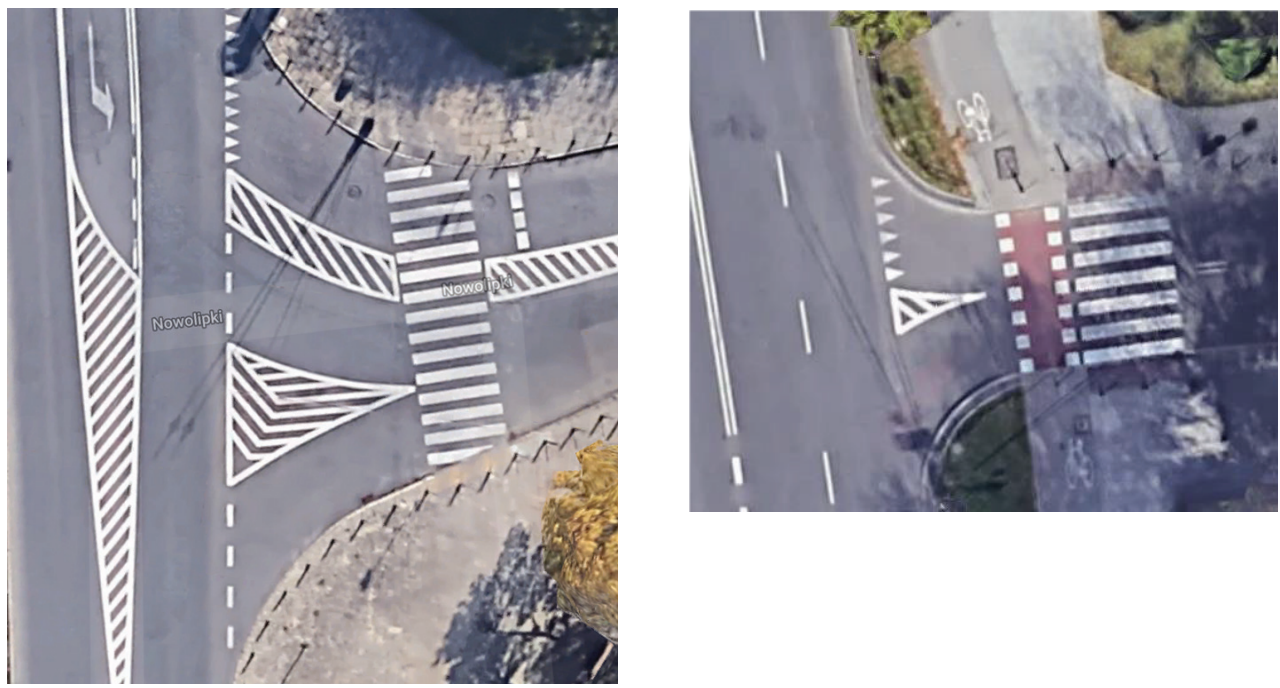

Fig. 9. Crossings across Nowolipki (left) and Matejki (right) in Warsaw Source: Google Maps 
The presence of a bicycle crossing and its being raised to sidewalk level resulted in a significant share of drivers clearly looking around before driving across (c. 75\% on both Srebrna and Wędrowców). This was a significantly higher share than when a non-raised bicycle crossing was present (46\%). The low efficacy of painted markings alone was confirmed by the way the hatched road markings were treated on Nowolipki, next to the Warsaw Police Station, where they were used as extra space to drive across the crossing without stopping when pedestrians were present. Such behavior was observed not only among car, but also bus drivers, sometimes resulting in the pedestrian needing to speed up or stop (cf. Fig. 10). In sum, the majority of drivers on Nowolipki drove across the crossing when there were non-motorized persons on it, including $40 \%$ who did so without stopping (cf. Fig. 11).

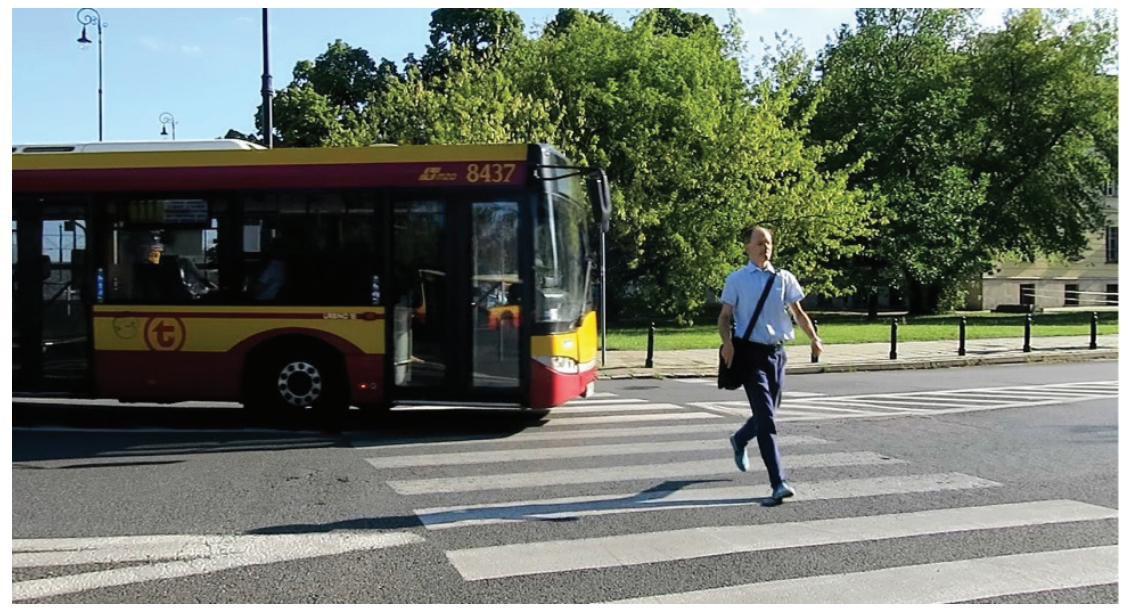

Fig. 10. A bus driving across the Nowolipki crossing without slowing down, across the hatched markings Phot. M. Sulmicki

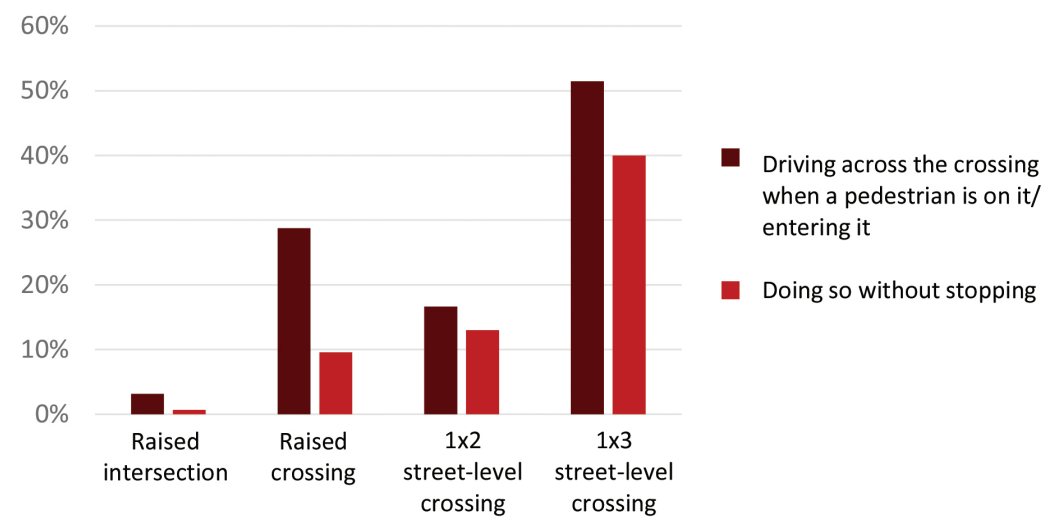

Fig. 11. Share of drivers driving across T-type crossings on roads of different widths and traffic calming measures when a non-motorized person was present 
A correlation is visible between the road width, traffic calming measures and the likelihood of drivers actually giving way to pedestrians. Different behavior towards pedestrians on crossings was visible even among student drivers (cf. Figs. 13 and 14). The higher share of drivers driving across a raised pedestrian and bicycle crossing across a two-lane road when non-motorized persons were present than across a street-level one may be partly explained by the similar speeds of cars and pedestrians/cyclists resulting from the physical traffic calming measures. In effect, the raised crossing functioned in a similar manner to shared space, i.e. an area where all road users are to move smoothly, one by one at a similar speed. Such an approach appears to be confirmed by the aforementioned high share of drivers clearly looking around before entering the raised crossing and the marginal number of drivers driving fast across it.

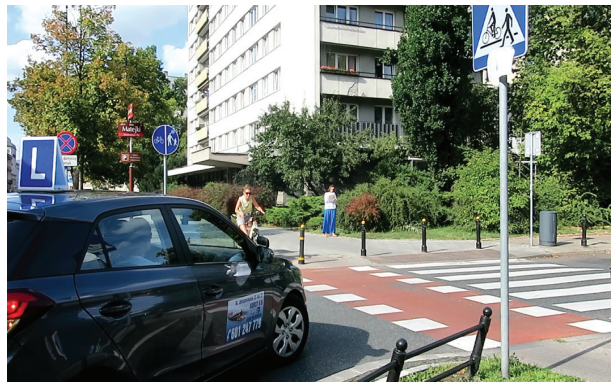

Fig. 12. A student driver with instructor giving way to a cyclist entering the Matejki crossing in Warsaw

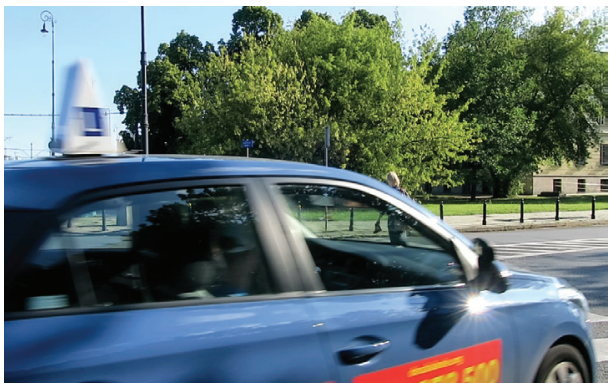

Fig. 13. A student driver with instructor driving fast behind a pedestrian on the Nowolipki crossing in Warsaw

Phot. M. Sulmicki

\section{Crossings across intersections with traffic lights}

The observed crossings across intersections with traffic lights were chosen so as to take into account the possibility of a conditional right-turn (red light with a green arrow), the type of intersection (three- or four-way) and the presence of refuge islands. In effect, 4 crossings in Warsaw and 1 in Radom were chosen:

- two across three-way intersections with conditional right turns (pedestrian and bicycle crossings with a refuge island across Nowy Zjazd along Wybrzeże Kościuszkowskie and a pedestrian crossing without a refuge island across Sierakowskiego along al. Solidarności in Warsaw; in the latter case, drivers turning right from al. Solidarności during their green light were also observed),

- two across four-way intersections with conditional right turns (pedestrian crossings with refuge islands across Nugat and Rosoła in Warsaw and ones without refuge islands across 25 Czerwca and Żeromskiego in Radom),

- one across a four-way intersection without a conditional right turn (pedestrian and bicycle crossing with refuge island across al. Rzeczypospolitej along Klimczaka in Warsaw). 
The observations confirmed the results of earlier studies which indicated that a red light with a conditional right turn allowed after stopping allowed is treated by default as a green right-turn light. However, while earlier studies indicated that around $1 \%$ of drivers respect the obligation to stop before entering the intersection in such a situation [cf. Głowacka et al. 2010 , pp. 630-631], the share of drivers who did so on the observed intersections was $22 \%$, although the definite majority did so because of non-motorized persons being present. When there was a red light with a conditional right turn, but there were no pedestrians or cyclists on the crossing or right next to it, $93 \%$ of drivers drove across the crossing without stopping.

A significant share of drivers drove fast across the crossing during a red light with a conditional right turn: $22 \%$, excluding the intersection in Radom, where the traffic intensity was c. 1000 vehicles per hour, which made driving fast difficult. A correlation was visible between the lane and driver speed: $8 \%$ of drivers drove fast across the crossing on Nugat (3.5-meter lane), while $26 \%$, i.e. 3 times more, did so on Nowy Zjazd (4.5-meter lane) (cf. Figs. 14 and 15), despite the presence of a bicycle crossing on Nowy Zjazd, which meant that the drivers, turning conditions of visibility limited by cars waiting in the next lanes to the left, were obliged to give way to cyclists moving in a straight line during a green light. Although the road curve radius was the same in both cases, the curve on Nowy Zjazd began before the crossing. Along with the feeder lane behind the crossing, this resulted in frequent speeding up before the crossing in order to drive fast across it, despite the red light.
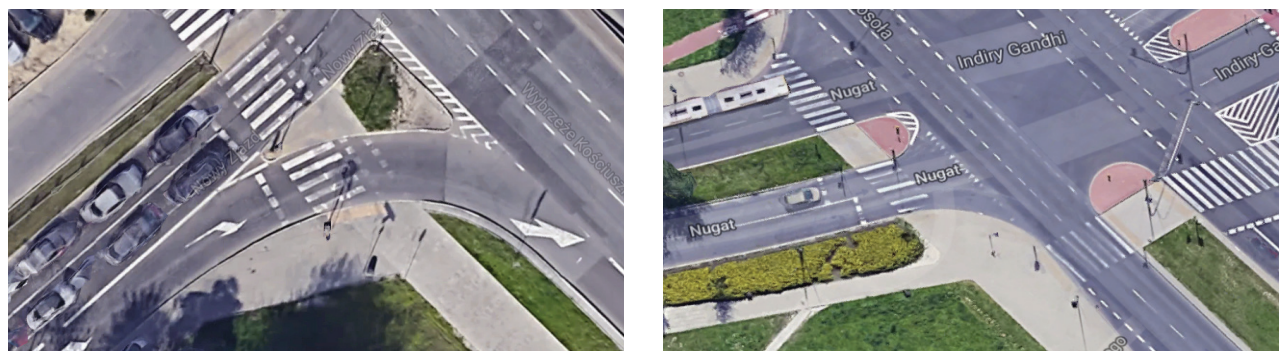

Figs. 14 and 15. Bird's-eye view of the observed fragments of the Nowy Zjazd / Wybrzeże Kościuszkowskie and Nugat / Rosoła intersections

Source: Google Maps

A strong correlation was also observed between the road width/number of lanes and the likelihood of drivers driving across despite the presence of pedestrians on the crossing (cf. Fig. 16). In the case of the 25 Czerwca / Żeromskiego crossings in Radom and the one across Sierakowskiego in Warsaw (across 4-5 lanes each), nearly 2/3 of drivers did not wait for the pedestrian to leave the crossing (cf. Fig. 17). This was 3.5 times more than in the case of a crossing across one, albeit wide, lane on Nowy Zjazd or along a bus/tram platform in al. Solidarności). Nevertheless, even in these one-lane cases, the lane width encouraged 18\% of drivers not to wait for the pedestrian to leave the crossing before driving across it. When the crossing was two lanes wide, one out of four drivers did not wait (cf. Fig. 18). The more narrow the road, the greater the share of pedestrians who were at least near/in the process of leaving the crossing in such a situation. 


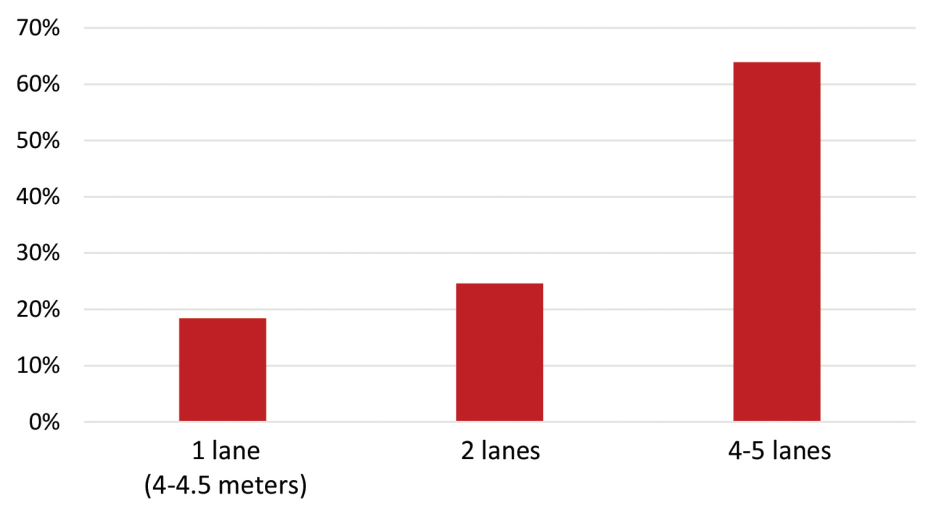

Fig. 16. Share of drivers driving across a crossing on which a non-motorized person is present on intersections with traffic lights, depending on road width

Source: own work

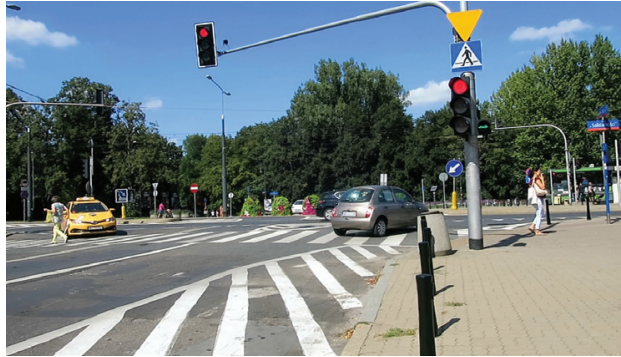

Fig. 17. Cars driving across the crossing on Sierakowskiego in Warsaw when a pedestrian is present

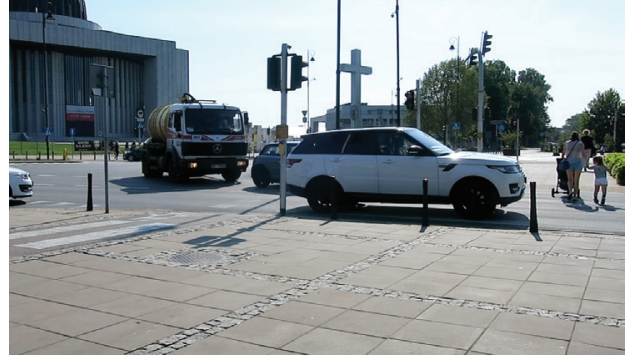

Fig. 18. Cars driving across the crossing on al. Rzeczypospolitej in Warsaw when pedestrians are present

Phot. M. Sulmicki

Another problem resulting from the conditional permission to turn right on a red light was the higher frequency of driving onto the pedestrian crossing without the possibility of leaving it. On the three crossings with green arrows where right-turns were analyzed (Nowy Zjazd, Sierakowskiego, Nugat), $12 \%$ of drivers stopped on the crossing itself, i.e. twice as many as on T-shaped intersections without traffic lights (cf. Fig. 19).

The possibility of a conditional right-turn also resulted in drivers not respecting the obligation to stop on a red light, not only when the green arrow was on, but also when it wasn't. Of the drivers turning right when the traffic lights were visible, $10 \%$ did so on a yellow or red light without a green arrow, some of them doing so even 30 seconds after the red light turned on. The very presence of a S-2 (green arrow) signal was treated as permission for ignoring the traffic lights altogether when turning right. 


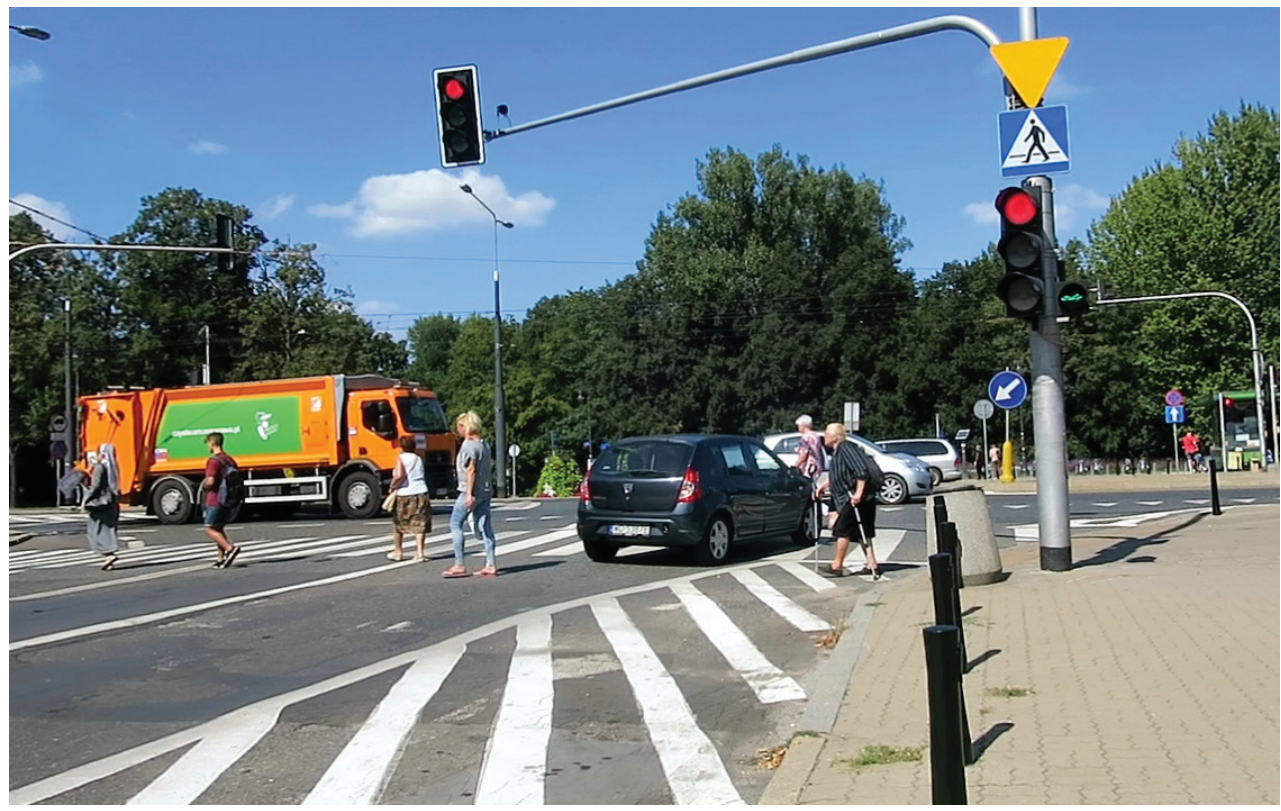

Fig. 19. A car standing on the crossing across Sierakowskiego in Warsaw, having driven onto it on a red light, $2-3$ seconds after the green arrow was turned off

Phot. M. Sulmicki

\section{Pedestrian crossings on roundabouts}

The pedestrian crossings on roundabouts were chosen, so as to take into account the roundabout and central island diameter and the road width on the crossing. In effect, 2 crossings in Warsaw and 1 in Radom were analyzed:

- 2 on medium roundabouts (42-meter diameter, 25-28-meter central island and crossings across two lanes in each direction (the eastern arm of the Żegańska / Dworcowa roundabout in Warsaw and the south-eastern arm of the Dmowskiego roundabout in Radom),

- 1 on a small one-lane roundabout (24-meter diameter, 14-meter central island and crossings one lane in each direction (pedestrian and cycle crossing across the south-western arm of the Klimczaka / Sarmacka roundabout in Warsaw).

All the crossings were equipped with refuge islands.

The impact of one-lane-wide crossings on pedestrian traffic flow smoothness was visible - pedestrians never had to wait to cross the road. On the medium roundabouts, $1 / 8$ of the non-motorized did. Greater confidence on the part of the non-motorized was correlated with more caution on the part of the drivers. On the one-lane roundabout, most drivers looked around before driving across the pedestrian/bicycle crossing. On the medium two-lane roundabout, drivers by default looked straight ahead, at the road, even though on the Radom roundabout there was also both a pedestrian and a bicycle crossing. 


\section{THE IMPACT OF INFRASTRUCTURE ON DRIVER BEHAVIOR ON PEDESTRIAN CROSSINGS... \\ Maciej Sulmicki}

As in the remaining cases, the greater number of lanes before the crossing resulted in a lesser probability of the driver stopping before the crossing when a non-motorized person was approaching or entering it. On two-lane roundabouts, drivers stopped mostly when the pedestrian was approaching from the side of the road on which they were driving. Some of those driving on the other lane overtook cars giving way to pedestrians/cyclists, thus increasing the risk of an accident and making pedestrians more cautious, tending to wait until cars stop on both lanes before entering the crossing (cf. Fig. 20).
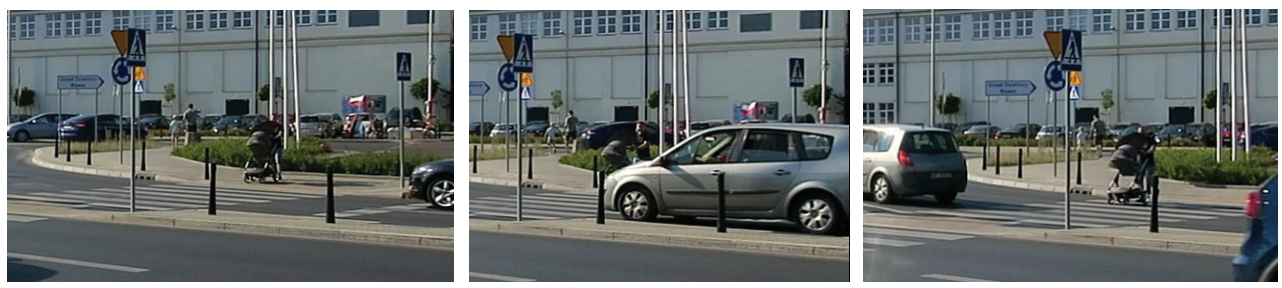

Fig. 20. A driver overtaking a car which stopped to let a person with a baby carriage cross Żegańska in Warsaw when the pedestrian is entering the crossing

Phot. M. Sulmicki

The behavior of drivers on roundabouts also confirmed that excessively wide lanes encourage driving across a crossing on which a pedestrian is present. In the case of the small roundabout, the lanes were 4.5-meters wide, even though regulations allow for 3.5-meter lanes on small and mini roundabouts. In effect, $1 / 3$ of the drivers drove across the crossing despite a pedestrian being present on it or entering it (cf. Fig. 21) - a value analogical to that of medium roundabouts ( 2 lanes, 7 meters wide in total), although on medium roundabouts the drivers did so at a greater speed.

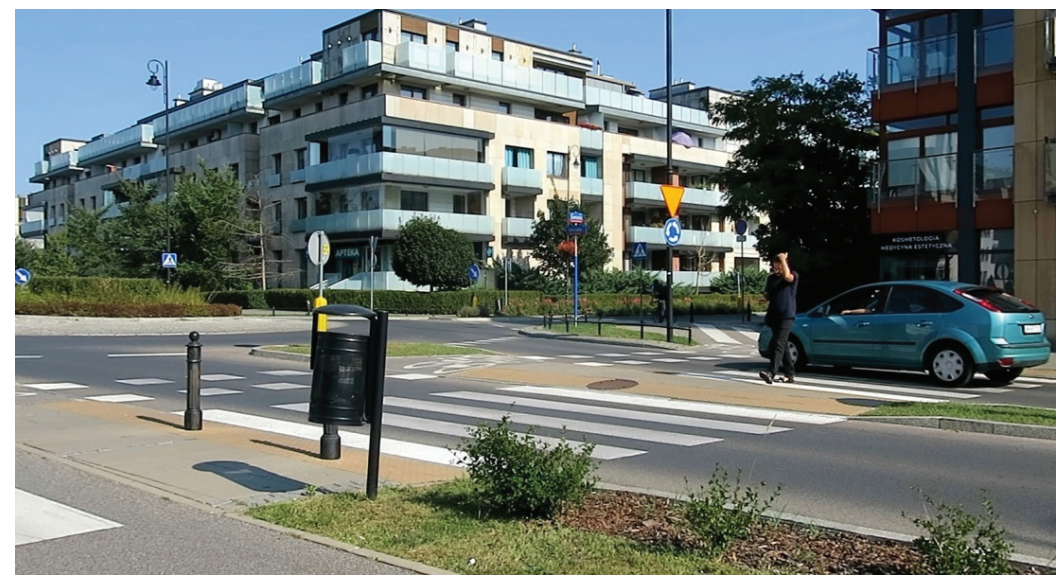

Fig. 21. A driver driving behind a pedestrian on a crossing across Klimczaka in Warsaw Phot. M. Sulmicki 


\section{Conclusions}

The results of the observations and analyses indicate that:

- the strategic and spatial planning documents of the Mazovia region are accurate in their prescriptions concerning the need to use physical means of traffic calming,

- the prescriptions should be transposed to local documents and practice,

- in order for traffic safety to improve, the approach to designing infrastructure for the non-motorized needs to be more standardized, in line with more detailed prescriptions in line with the regional documents,

- raised pedestrian crossings should be the default solution in cases when the crossing leads across a side road, so as to emphasize the fact that the pedestrians moving along the major road should have priority before those turning from it or onto it,

- $\quad$ raised pedestrian crossings and small/mini roundabouts should be the default solution on side road intersections,

- the width of the road on a pedestrian crossing should be minimalized,

- the regulations concerning right of way on pedestrian crossings should clearly indicate that a driver is obliged to give way to a pedestrian who is nearing or entering such a crossing, as is the case with giving way to an approaching vehicle which has the right of way; the field studies showed that the frequency of drivers driving in front of a pedestrian entering the crossing is three and a half times higher than in front of a pedestrian already on the crossing (once his priority is undoubtable, also according to current Polish regulations).

Furthermore, the following conclusions should be taken into account:

- $\quad$ raised pedestrian and bicycle crossings are a much more effective method of traffic calming in places of potential non-motorized/motorized collisions than painted road markings,

- $\quad$ excessive road width encourages drivers to drive across crossings on which a pedestrian is present, even if there is only one lane,

- pedestrian traffic flow is smoother on crossings without traffic lights,

- on crossings with traffic lights, the green light for pedestrians turning on earlier than the colliding green arrow limits the number of situations in which a driver drives onto the crossing when a pedestrian is entering it,

- $\quad$ a red light with the conditional permission to turn right after stopping is treated by drivers as a green right-turn light,

- bicycle crossings on which the driver is obliged to give way increase drivers' caution, resulting in more cautious driving; this effect may be cancelled by traffic lights (green arrows in particular), geometry and road markings (i.e. the two-lane roundabout exit with "give way" signs behind, rather than in front of the bicycle crossing on the roundabout in Radom),

- the lack of clear regulations concerning the priority of pedestrians on crossings worsens traffic flow due to the resulting mutual lack of trust, both on the part of drivers, and 
pedestrians who can't be sure when they will be given way; this results in waiting until the car stops completely before entering the crossing. This effect is particularly visible on crossings across more than one lane.

\section{References}

Budzyński M., Jamroz K., Mackun T., 2017, Pedestrian Safety in Road Traffic in Poland, 2017, IOP Conf. Series: Materials Science and Engineering, 245 042064, pp. 1-9.

Głowacka J., Kidawa J., Sierpiński G., 2010, Ocena warunków ruchu w sytuacji zastosowania sygnału dopuszczającego skręcanie w kierunku wskazanym strzałka dla wybranych skrzyżowań z sygnalizacja świetlna w Katowicach, Logistyka, 2, pp. 621-632.

Ministerstwo Infrastruktury, Sekretariat Krajowej Rady Bezpieczeństwa Ruchu Drogowego, 2019, Badania zachowań pieszych i relacji pieszy-kierowca wrzesień-grudzień 2018 r., Warszawa.

Skoczyński P., Wacowska-Ślęzak J., 2019, Bezpieczeństwo ruchu drogowego w Polsce w 2018 roku. Analiza danych o wypadkach drogowych, Polskie Obserwatorium Bezpieczeństwa Ruchu Drogowego,

http://www.obserwatoriumbrd.pl/resource/c17a26eb-a594-48c3-bf3e-b71717392b9b:JCR.

Vaa T., 2006, Understanding driver/pedestrian conflicts: Driver behaviour and effect of measures at pedestrian crossings, 19th ICTCT Workshop. Proceedings, Section 3, pp. 1-11.

\section{Legal acts and documents}

Rozporządzenie Ministrów Infrastruktury oraz Spraw Wewnętrznych i Administracji z dnia 31 lipca 2002 r. w sprawie znaków i sygnałów drogowych (Dz.U.2019.0.2310).

Plan zagospodarowania przestrzennego województwa mazowieckiego, adopted by Uchwała nr 22/18 Sejmiku Województwa Mazowieckiego z dnia 19 grudnia 2018 r.

Projekt ustawy o zmianie ustawy - Prawo o ruchu drogowym oraz ustawy o kierujących pojazdami z dnia 30 stycznia $2020 \mathrm{r}$.

Strategia rozwoju Obszaru Metropolitalnego Warszawy do roku 2030, 2015, metropolia warszawska, omw.um.warszawa.pl

Strategia rozwoju województwa mazowieckiego do 2030 roku. Innowacyjne Mazowsze, adopted by Uchwała nr 158/13 Sejmiku Województwa Mazowieckiego z dnia 28 października 2013 r. 


\section{Wpływ infrastruktury na zachowania kierowców na przejściach dla pieszych na przykładzie Warszawy i Radomia}

\section{STRESZCZENIE}

W 2019 r. przeprowadzone zostały badania wpływu rozwiązań infrastrukturalnych na przejściach dla pieszych i przejazdach dla rowerzystów na zachowania kierowców. Celem ramowym przeprowadzonych badań była weryfikacja trafności zapisów zawartych w dokumentach strategicznych i planistycznych Województwa Mazowieckiego odnoszących się do bezpieczeństwa ruchu drogowego. Lokalizacje w Warszawie i Radomiu zostały dobrane w taki sposób, aby uwzględnione zostały wszystkie wymienione w Planie zagospodarowania przestrzennego województwa mazowieckiego rodzaje uspokojenia ruchu, mające służyć poprawie bezpieczeństwa i dotyczące bezpośrednio przejść dla pieszych. Jednocześnie pod uwagę brane były takie czynniki jak przekrój jezdni, układ skrzyżowania i sygnalizacja świetlna.

Podczas badań obserwowano zachowania kierowców względem niezmotoryzowanych oraz te, które determinowały możliwość szybkiego zareagowania na pojawienie się niezmotoryzowanego uczestnika ruchu. Badania były prowadzone z punktów obserwacyjnych oddalonych od skrzyżowania, by nie wpływać na zachowanie uczestników ruchu. Na podstawie co najmniej trzydziestominutowych obserwacji w terenie oraz późniejszej analizy nagrań notowano, czy: kierowca zatrzymuje się przed przejściem, wjeżdża przed lub za niezmotoryzowanego, zatrzymuje się na przejściu, wjeżdża szybko na przejście. W wybranych lokalizacjach analizowano również, czy kierowca rozgląda się przed wjazdem na przejście, jednak w większości miejsc nie było to możliwe ze względu na duże natężenie ruchu i/lub nieodpowiednią widoczność. Obserwacje w Radomiu zostały przeprowadzone przez Sebastiana Pawłowskiego i Łukasza Zaborowskiego z Mazowieckiego Biura Planowania Regionalnego, Oddziału Terenowego w Radomiu.

Wyniki badań wskazuja, że na niebezpieczne zachowania kierowców mają wpływ: przekrój jezdni na przejściu dla pieszych, obecność przejazdów dla rowerzystów i zasady pierwszeństwa, fizyczne środki uspokojenia ruchu oraz sygnalizacja świetlna. Wykazano, że nieskutecznym rozwiązaniem jest powierzchnia wyłączona z ruchu jedynie za pomocą oznakowania poziomego oraz czerwone światło z dopuszczonym warunkowym prawoskrętem (zieloną strzałką), które traktowane jest jako zielone światło.

Badania potwierdziły słuszność zapisów zawartych w dokumentach strategicznych i planistycznych województwa mazowieckiego, jak też konieczność ich szerszego stosowania. Analiza wyników badań terenowych pozwoliła wykazać konkretne zależności pomiędzy różnymi parametrami rozwiązań a ich wpływem na zachowania kierowców, co stanowi uzupełnienie wcześniejszych badań lokalnych oraz badań z 2018 r. na poziomie krajowym.

Słowa kluczowe: bezpieczeństwo ruchu drogowego, przejścia dla pieszych, niechronieni uczestnicy ruchu, uspokojenie ruchu

\footnotetext{
Maciej Sulmicki, PhD - key specialist in the Mazovian Office for Regional Planning, member of the Green Mazovia Association, lecturer at Vistula University. Specializes in sustainable transport, with particular emphasis on pedestrian and bicycle traffic. Contact: Mazovian Office for Regional Planning, ul. Nowy Zjazd 1, 00-301 Warszawa, e-mail:msulmicki@mbpr.pl

Maciej Sulmicki, dr - główny specjalista w Mazowieckim Biurze Planowania Regionalnego, członek stowarzyszenia Zielone Mazowsze, adiunkt w Akademii Finansów i Biznesu Vistula. Specjalizuje się w problematyce transportu zgodnego z zasadami trwałego rozwoju, ze szczególnym naciskiem na ruch pieszy i rowerowy; kontakt do autora: Mazowieckie Biuro Planowania Regionalnego, ul. Nowy Zjazd 1, 00-301 Warszawa, e-mail:msulmicki@mbpr.pl
} 